\title{
Knowledge, attitudes and behaviours towards people with HIV and AIDS among private higher education students in Johannesburg, South Africa
}

\begin{tabular}{|c|c|}
\hline \multicolumn{2}{|c|}{$\begin{array}{l}\text { Authors: } \\
\text { Natasha Khamisa }{ }^{1} \\
\text { Maboe Mokgobi } \\
\text { Tariro Basera }{ }^{3}\end{array}$} \\
\hline \multicolumn{2}{|c|}{$\begin{array}{l}\text { Affiliations: } \\
{ }^{1} \text { Department of Public Health, } \\
\text { School of Engineering, IT, } \\
\text { Science and Health, IIE MSA, } \\
\text { Johannesburg, South Africa }\end{array}$} \\
\hline \multicolumn{2}{|c|}{$\begin{array}{l}{ }^{2} \text { Department of Psychology, } \\
\text { School of Social Science, } \\
\text { IIE MSA, Johannesburg, } \\
\text { South Africa }\end{array}$} \\
\hline \multicolumn{2}{|c|}{$\begin{array}{l}{ }^{3} \text { Médecins Sans Frontières, } \\
\text { Rustenburg, South Africa }\end{array}$} \\
\hline \multicolumn{2}{|c|}{$\begin{array}{l}\text { Project Research Number: } \\
\text { CF15/1095-2015000518c }\end{array}$} \\
\hline \multicolumn{2}{|c|}{$\begin{array}{l}\text { Corresponding author: } \\
\text { Natasha Khamisa, } \\
\text { natasha.khamisa@monash. } \\
\text { edu }\end{array}$} \\
\hline \multicolumn{2}{|c|}{$\begin{array}{l}\text { Received: } 11 \text { June } 2019 \\
\text { Accepted: } 11 \text { Dec. } 2019 \\
\text { Published: } 24 \text { Mar. } 2020\end{array}$} \\
\hline \multicolumn{2}{|c|}{$\begin{array}{l}\text { How to cite this article: } \\
\text { Khamisa N, Mokgobi M, } \\
\text { Basera T. Knowledge, } \\
\text { attitudes and behaviours } \\
\text { towards people with HIV and } \\
\text { AIDS among private higher } \\
\text { education students in } \\
\text { Johannesburg, South Africa. } \\
\text { S Afr J HIV Med. 2020;21(1), } \\
\text { a991. https://doi.org/ } \\
\text { 10.4102/sajhivmed.v21i1.991 }\end{array}$} \\
\hline \multicolumn{2}{|c|}{$\begin{array}{l}\text { Copyright: } \\
\text { ( 2020. The Authors. } \\
\text { Licensee: AOSIS. This work } \\
\text { is licensed under the } \\
\text { Creative Commons } \\
\text { Attribution License. }\end{array}$} \\
\hline \multirow[b]{2}{*}{ 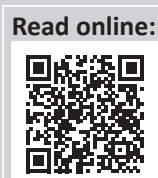 } & \\
\hline & $\begin{array}{l}\text { Scan this QR } \\
\text { code with your } \\
\text { smart phone or } \\
\text { mobile device } \\
\text { to read online. }\end{array}$ \\
\hline
\end{tabular}

Background: Human immunodeficiency virus and acquired immunodeficiency syndrome (HIV and AIDS) is a global health and social problem, with South Africa having an estimated overall prevalence rate of $13.5 \%$. Compared to young male participants, young female participants have been reported to have less knowledge about HIV and AIDS, including prevention strategies, and this is associated with risky sexual behaviours and negative attitudes towards condom use.

Objectives: The study investigated gender differences in knowledge, attitudes and behaviours towards HIV and AIDS among 542 private higher education students in Johannesburg, South Africa.

Method: Participants completed an online structured questionnaire measuring knowledge, attitudes and behaviours as well as demographics (including age, gender and relationship status).

Results: The results indicate that overall there were no significant differences between male and female students in terms of HIV and AIDS knowledge. However, female students had significantly less knowledge with regard to unprotected anal sex as a risk factor for HIV and AIDS. In addition, young female students reported condom use at last sex less frequently than male students. Nonetheless, both genders reported a positive attitude towards condom use and towards people living with HIV and AIDS.

Conclusion: It is recommended that the relevant authorities at the state and the higher education level seriously consider implementing specific strategies for preventing HIV and AIDS through improved knowledge, attitudes and behaviours among young females.

Keywords: attitudes about contraception; levels of knowledge; risky sexual behaviours; gender differences; young female students.

\section{Introduction}

Since the beginning of the epidemic, human immunodeficiency virus and acquired immunodeficiency syndrome (HIV and AIDS) has affected more than 70 million people globally, accounting for 35 million deaths. ${ }^{1}$ As of 2018, over $30 \%$ of the global HIV and AIDS prevalence has been among the youth aged 15-25 years, with 5 million young people currently living with HIV and AIDS. ${ }^{1}$ The youth between the ages of 15 and 24 years account for $45 \%$ of new infections. ${ }^{2}$ The burden of HIV and AIDS is concentrated in sub-Saharan Africa, where $71 \%$ of people living with HIV reside and where 65\% of new infections reported in 2017 occurred. ${ }^{3}$ The female population is disproportionately affected by HIV, with three in four new infections reported among girls aged 15-19 years, while the young female population aged 15-24 years is twice as likely to be living with HIV and AIDS than their male counterparts. ${ }^{4}$

South Africa is known to have one of the highest rates of HIV and AIDS globally and on the African continent. It is estimated that 7.97 million South Africans (13.5\%) are living with HIV and AIDS, and over a fifth of these are females of reproductive age (15-49 years). Gauteng Province, the most populous province in the country ( $25.8 \%$ of the population), is home to over 2 million young people, the majority of whom are females. ${ }^{5}$ The high infection rate among the young female population is attributed to a lack of knowledge as well as poor attitudes towards the use of condoms and risky sexual behaviour. ${ }^{6}$ Knowledge regarding HIV and AIDS infection is necessary to correct negative attitudes towards condom use and to encourage healthy sexual behaviour 
among the youth by improving their ability to practice safe sex. This is likely to improve the uptake of HIV prevention strategies to address the increase in the prevalence of HIV and AIDS in vulnerable populations. ${ }^{6,7}$ Young female participants are twice as likely to be infected with HIV and AIDS, compared to young male participants, with the most common means of transmission being unprotected sex, and the key barriers to prevention being lack of knowledge, negative attitudes and risky sexual behaviour. ${ }^{3,6,8}$

Knowledge facilitates familiarity with and awareness of HIV and AIDS, which influences attitudes (resulting in support and motivation for prevention) as well as behaviour (safer sex practices), thereby reducing the risk of infection. ${ }^{9}$ A high prevalence of HIV and AIDS is associated with lower levels of knowledge about the modes of transmission and condom use, negative attitudes towards condom use and risky sexual behaviours such as unsafe sex and multiple sex partners. ${ }^{10,11}$ The young female population has been shown to possess significantly lower levels of knowledge as well as misconceptions and erroneous beliefs about HIV and AIDS, compared to the male population. ${ }^{6,12}$ This is often associated with negative attitudes to prevention strategies, which have been shown to affect behaviours such as condom use. ${ }^{13}$ Studies have also confirmed that HIV and AIDS testing attitudes and the intention to use condoms are influenced by knowledge. ${ }^{14,15}$

Charles et al. ${ }^{16}$ reveal that although the young female population is more concerned about HIV and AIDS infection, they agree less than the young male population on condom use as a safe sex strategy. The attitudinal gender differences of the young female population with regard to transactional sex are thought to result in risky behaviours such as unprotected sex with older men. ${ }^{17}$

Although it is known that the young female population is more susceptible to HIV and AIDS infection, there is a paucity of research on gender differences in knowledge, attitudes and behaviours among young people in higher education settings, thereby inhibiting an in-depth understanding of factors contributing to HIV and AIDS infection among this population in South Africa. Such a gap in the literature negatively influences policy and practice aimed at reducing HIV and AIDS rates among vulnerable youth within this context. This study was aimed at identifying gender differences in knowledge, attitudes and behaviours among the youth at a private higher education institution in Johannesburg, South Africa. It is envisaged that this will allow for the development of specific strategies for preventing HIV and AIDS infection among the youth at private higher education institutions in South Africa. The research question seeks to determine differences between the male and female populations on knowledge, attitudes and behaviours towards HIV and AIDS. It is hypothesised that knowledge, attitudes and behaviours will differ between the male and the female populations.

\section{Methods Study design}

This cross-sectional survey was conducted at a private higher education institution in Johannesburg, South Africa. Participants were invited via an online learning platform where they completed and submitted a structured questionnaire assessing sexual risk and sexual prevention behaviours.

\section{Setting}

Johannesburg is the capital of Gauteng province and is considered the largest and the wealthiest city in South Africa. With a population estimated at 5.6 million, it is the most populous city in the country, with $66 \%$ growth rate in population expected over the next 30 years. Racial profiles indicate that $76.4 \%$ of the population is black African, $5.6 \%$ is mixed race, $12.3 \%$ is white or of European descent and $4.9 \%$ is of Indian or Asian descent. Approximately, $7 \%$ of the population is illiterate, $3.4 \%$ have only a primary education, $41 \%$ have completed secondary education and $6 \%$ have a tertiary qualification. ${ }^{18}$

\section{Study population and sampling}

Random sampling was used to recruit 845 students enrolled at a private higher education institution in Johannesburg, South Africa. Random numbers were generated using a computer program to select participants from the sampling frame - enrolment records. A global email was sent to all potential participants inviting them to participate in the study. Of those invited to participate in the study, 542 responded - a response rate of $64 \%$. Participants completed an online questionnaire via their online learning platform, which contained study information and instructions for accessing and completing the questionnaire.

\section{Data collection and analysis}

An online structured questionnaire measuring knowledge, attitudes and behaviours as well as demographics (including age, gender and relationship status) was completed by the participants. The questionnaire was developed as part of a larger study using existing literature and consisted of 93 questions of which 51 questions were on knowledge about HIV and AIDS transmission and prevention, attitudes towards HIV and AIDS, including treatment and prevention methods (six questions), and sexual behaviours (36 questions).

Data were cleaned and checked for errors before coding and analysing using STATA 14.0 (StataCorp, College Station, TX, USA). To evaluate knowledge and behaviours, respondents were required to provide mostly 'yes' or 'no' responses. For the knowledge score, a score of 1 was assigned for a correct answer and 0 for a wrong answer. For the attitude questions, a rank was assigned using the Relative Importance Index to obtain an overall rank for each attitude item. For knowledge, attitudes and practice questions (knowledge and awareness 
of HIV \& AIDS, prevention and control of HIV, students' attitudes towards condom use and people living with HIV, risky sexual behaviours), the frequency of responses in each category was determined. A chi-square test was used to evaluate the variation in knowledge, attitude and behaviour between male and female students. For all tests, $p<0.05$ was considered statistically significant.

\section{Ethical considerations}

Ethical approval to conduct the study was obtained from Monash University Human Research Ethics Committee (MUHREC) (approval number CF15/1095 - 2015000518). No identifying information was obtained from students when they completed the questionnaire. A unique identifier was generated when the questionnaire was submitted. All the data were deidentified for analysis. Data were stored in password-protected files and will be retained for up to 5 years after the study.

\section{Results}

\section{Socio-demographic characteristics of the students}

Data were collected from 542 students, 374 (69.0\%) of whom were female students. The participants had a median age of 19 years (interquartile range $[\mathrm{IQR}]=16-30$ years), and their average knowledge score of HIV and AIDS and sexually transmitted infections (STIs) was 0.78 (standard deviation $[S D]=0.17) ; 397(73.2 \%)$ students were black Africans, $67(12.4 \%)$ students were whites, $44(8.1 \%)$ students were of Indian/Asian descent and 29 (5.4\%) students were of mixed race; $427(80.6 \%)$ students were single and $88(16.6 \%)$ students were in a stable relationship. Most of the students were in the Higher Certificate, Higher Education Studies' stream ( $n=357,71.1 \%)$, and 145 (28.9\%) students were undergraduates (Table 1).

There were high levels of awareness and knowledge about biomedical methods of HIV prevention amongst the sample group. More female (77.1\%) than male students $(64.1 \%$, $p=0.003$ ) said that they had heard about medication that HIV-positive pregnant women could take to reduce the risk of infecting the baby with HIV, and more female (59.9\%) than male students $(47.6 \%, p=0.015)$ had heard about medication that could help to reduce the risk of HIV infection if a woman had been raped. A higher proportion of male $(95.8 \%)$ versus female students $(85.7 \%, p=0.001)$ said that they were able to obtain a condom. There was no significant difference between the proportion of male (97.0\%) and female students (94.1\%) about where to get condoms (Table 2).

Knowledge about HIV transmission was high, with $98.1 \%$ of female students and $96.4 \%$ of male students knowing that the virus could be passed on through unprotected sex. A high proportion of male students $(92.9 \%)$ and female students $(90.9 \%)$ knew that a person can have HIV and pass it on to others without showing symptoms. Also, most female students $(77.4 \%)$ and male students $(76.8 \%)$ knew that STIs put people at greater risk of HIV infection. However, only $33.6 \%$ of female students and $39.3 \%$ of male students admitted
TABLE 1: Socio-demographic characteristics of students.

\begin{tabular}{|c|c|c|}
\hline Variable & $n$ & $\%$ \\
\hline \multicolumn{3}{|l|}{ Age $(N=542)$} \\
\hline $15-19$ & 375 & 69.2 \\
\hline $20-32$ & 167 & 30.8 \\
\hline \multicolumn{3}{|l|}{$\operatorname{Sex}(N=542)$} \\
\hline Male & 168 & 31.0 \\
\hline Female & 374 & 69.0 \\
\hline \multicolumn{3}{|l|}{ Population group ( $N=542$ ) } \\
\hline Black African & 397 & 73.2 \\
\hline White & 67 & 12.4 \\
\hline Mixed race & 29 & 5.4 \\
\hline Indian or Asian & 44 & 8.1 \\
\hline Other & 5 & 0.9 \\
\hline \multicolumn{3}{|l|}{ Religion $(N=529) \dagger$} \\
\hline African traditional & 16 & 3.0 \\
\hline Christian & 425 & 80.3 \\
\hline Muslim & 25 & 4.7 \\
\hline Hindu & 18 & 3.4 \\
\hline No religion & 40 & 7.6 \\
\hline Other & 5 & 1.0 \\
\hline \multicolumn{3}{|l|}{ Citizenship ( $N=542)$} \\
\hline South African & 378 & 69.7 \\
\hline Non-South African & 164 & 30.3 \\
\hline \multicolumn{3}{|l|}{ Relationship status $(N=530) \dagger$} \\
\hline Single & 427 & 80.6 \\
\hline Going steady & 88 & 16.6 \\
\hline In a relationship or cohabiting & 3 & 0.6 \\
\hline Divorced or widowed & 3 & 0.6 \\
\hline Married & 9 & 1.7 \\
\hline \multicolumn{3}{|l|}{ Living arrangements $(N=537) \dagger$} \\
\hline In a relationship but not living together & 80 & 14.9 \\
\hline Living with boyfriend or girlfriend or partner & 13 & 2.4 \\
\hline Living alone & 106 & 19.7 \\
\hline Living with friends or peers or fellow students or other people & 139 & 25.9 \\
\hline Living with family or relatives & 199 & 37.1 \\
\hline \multicolumn{3}{|l|}{ Locality type $(N=540) \dagger$} \\
\hline Campus accommodation & 143 & 26.5 \\
\hline Off-campus accommodation & 397 & 73.5 \\
\hline \multicolumn{3}{|l|}{ Level of study $(N=502) \dagger$} \\
\hline Higher Certificate in Higher Education Studies & 357 & 71.1 \\
\hline Undergraduate & 145 & 28.9 \\
\hline \multicolumn{3}{|l|}{ Financial situation of household ( $n=542)$} \\
\hline Not enough money for basic necessities like food and clothes & 10 & 1.9 \\
\hline $\begin{array}{l}\text { Have money for food and clothes, but short of many other } \\
\text { necessities }\end{array}$ & 59 & 10.8 \\
\hline Have most of the important things, but few luxury goods & 270 & 49.8 \\
\hline $\begin{array}{l}\text { Have some money for extra things such as going on a holiday and } \\
\text { buying luxury goods }\end{array}$ & 203 & 37.4 \\
\hline
\end{tabular}

$\dagger$, Missing values.

that they knew that anal sex increased the risk of HIV infection. A low proportion of female students (16.9\%) and male students (21.4\%) knew that people can reduce their chance of getting HIV by using a condom every time they have sex. More female (96.2\%) than male students (91.7\%) were aware that AIDS could not be cured. Most of the female students $(n=307,82.5 \%)$ and male students $(n=119,70.8 \%)$ indicated that partners could not have sexual intercourse if both partners were HIV-positive $(p=0.002)$ (Table 3$)$.

As illustrated in Table 4, a substantial number of students expressed positive attitudes towards condom use. Across age and gender groups, a significant majority of students 
TABLE 2: Student's knowledge of and access to HIV and AIDS prevention and control. Statement

\begin{tabular}{|c|c|c|c|c|c|c|c|c|}
\hline \multicolumn{4}{|c|}{ Female } & \multicolumn{4}{|c|}{ Male } & \multirow[t]{3}{*}{$p$} \\
\hline \multicolumn{2}{|c|}{ Yes } & \multicolumn{2}{|c|}{ No } & \multicolumn{2}{|c|}{ Yes } & \multicolumn{2}{|c|}{ No } & \\
\hline$n$ & $\%$ & $n$ & $\%$ & $n$ & $\%$ & $n$ & $\%$ & \\
\hline 350 & 94.1 & 22 & 5.9 & 163 & 97.0 & 5 & 3.0 & 0.147 \\
\hline 301 & 85.7 & 50 & 14.3 & 158 & 95.8 & 7 & 4.2 & $0.001 * * *$ \\
\hline 287 & 77.1 & 85 & 22.9 & 109 & 64.9 & 59 & 35.1 & $0.003 * * *$ \\
\hline 219 & 58.9 & 153 & 41.1 & 80 & 47.6 & 88 & 52.4 & $0.015 * * *$ \\
\hline
\end{tabular}

Do you know of a place where a person can get condoms?

If you wanted to, could you yourself get a condom?

Have you heard of drug treatments that HIV-positive pregnant women can take to reduce the risk of infecting the baby?

Have you heard of drug treatments that can help reduce the risk of HIV infection if a woman has been raped?

HIV, human immunodeficiency virus; AIDS, acquired immunodeficiency syndrome.

$* * *$, significant at $p<0.05$

TABLE 3a: Frequency and percentage of students' knowledge and awareness of HIV and AIDS.

\begin{tabular}{|c|c|c|c|c|c|c|c|c|c|}
\hline \multirow[t]{3}{*}{ Awareness of AIDS } & \multicolumn{4}{|c|}{ Female } & \multicolumn{4}{|c|}{ Male } & \multirow[t]{3}{*}{$p$} \\
\hline & \multicolumn{2}{|c|}{ Yes } & \multicolumn{2}{|c|}{ No } & \multicolumn{2}{|c|}{ Yes } & \multicolumn{2}{|c|}{ No } & \\
\hline & $n$ & $\%$ & $n$ & $\%$ & $n$ & $\%$ & $n$ & $\%$ & \\
\hline Have you ever heard of AIDS? & 350 & 94.1 & 22 & 5.9 & 157 & 93.4 & 11 & 6.6 & 0.776 \\
\hline
\end{tabular}

AIDS, acquired immunodeficiency syndrome.

TABLE 3b: Frequency and percentage of students' knowledge and awareness of HIV and AIDS. Knowledge about HIV and STI transmission

Female

\begin{tabular}{cccccc}
\multicolumn{5}{c}{ Female } \\
\hline \multicolumn{3}{c}{ True } & & \multicolumn{3}{c}{ False } \\
\cline { 1 - 2 } \cline { 4 - 6 } & & $\%$ & & $\%$
\end{tabular}

HIV can spread to males or females through unprotected sex

If a woman uses birth control pills or injection, it lowers her risk of getting infected with HIV

STIs put people at greater risk for HIV infection or infection with new forms of the virus

A person can have the AIDS virus and pass it on to others even if the person does not look sick

If both partners are HIV-positive, it is okay to have unprotected sex Having anal sex increases your chances of getting infected with HIV The HIV virus can be passed from a pregnant mother if she is infected with HIV to her unborn child

People can protect themselves from getting infected with the HIV virus by not having sexual intercourse

AIDS can be cured

Can people reduce their chances of getting the AIDS virus by using a condom every time they have sex

\begin{tabular}{ccccccccc}
$\boldsymbol{n}$ & $\mathbf{\%}$ & $\boldsymbol{n}$ & $\mathbf{\%}$ & $\boldsymbol{n}$ & $\mathbf{\%}$ & $\boldsymbol{n}$ & $\mathbf{\%}$ & \\
\hline 365 & 98.1 & 7 & 1.9 & 162 & 96.4 & 6 & 3.6 & 0.236 \\
47 & 12.6 & 325 & 87.4 & 30 & 17.9 & 138 & 82.1 & 0.108 \\
\hline 288 & 77.4 & 84 & 22.6 & 129 & 76.8 & 39 & 23.2 & 0.871 \\
338 & 90.9 & 34 & 9.1 & 156 & 92.9 & 12 & 7.1 & 0.442 \\
65 & 17.5 & 307 & 82.5 & 49 & 29.2 & 119 & 70.8 & $0.002^{* * *}$ \\
125 & 33.6 & 247 & 66.4 & 66 & 39.3 & 102 & 60.7 & 0.201 \\
312 & 83.9 & 60 & 16.1 & 139 & 82.7 & 29 & 17.3 & 0.743 \\
234 & 62.9 & 138 & 37.1 & 113 & 67.3 & 55 & 32.7 & 0.328 \\
14 & 3.8 & 358 & 96.2 & 14 & 8.3 & 154 & 91.7 & $0.027^{* * *}$ \\
63 & 16.9 & 309 & 83.1 & 36 & 21.4 & 132 & 78.6 & 0.212 \\
\hline
\end{tabular}

HIV, human immunodeficiency virus; AIDS, acquired immunodeficiency syndrome; STI, sexually transmitted infection.

$* * *$, significant at $p<0.05$

TABLE 4a: Student's attitudes related to condom use.

\begin{tabular}{|c|c|c|c|c|c|c|c|c|c|c|c|c|c|c|c|c|c|c|c|c|c|}
\hline \multirow[t]{3}{*}{ Variable } & \multirow[t]{3}{*}{ Total } & \multicolumn{4}{|c|}{$\begin{array}{l}\text { If I ask my sexual partner } \\
\text { to use a condom, he would } \\
\text { think I do not trust him }\end{array}$} & \multicolumn{4}{|c|}{$\begin{array}{l}\text { If I ask my sexual partner } \\
\text { to use a condom, he } \\
\text { might get angry }\end{array}$} & \multicolumn{4}{|c|}{$\begin{array}{l}\text { If I ask my partner to use } \\
\text { a condom, he might } \\
\text { get turned off }\end{array}$} & \multicolumn{4}{|c|}{$\begin{array}{l}\text { Condoms feel } \\
\text { unnatural }\end{array}$} & \multicolumn{4}{|c|}{$\begin{array}{l}\text { Condoms change the } \\
\text { climax or orgasm }\end{array}$} \\
\hline & & \multicolumn{2}{|c|}{ Agree } & \multicolumn{2}{|c|}{ Disagree } & \multicolumn{2}{|c|}{ Agree } & \multicolumn{2}{|c|}{ Disagree } & \multicolumn{2}{|c|}{ Agree } & \multicolumn{2}{|c|}{ Disagree } & \multicolumn{2}{|c|}{ Agree } & \multicolumn{2}{|c|}{ Disagree } & \multicolumn{2}{|c|}{ Agree } & \multicolumn{2}{|c|}{ Disagree } \\
\hline & & $n$ & $\%$ & $n$ & $\%$ & $n$ & $\%$ & $n$ & $\%$ & $n$ & $\%$ & $n$ & $\%$ & $n$ & $\%$ & $n$ & $\%$ & $n$ & $\%$ & $n$ & $\%$ \\
\hline \multicolumn{22}{|c|}{ Age (years) } \\
\hline $15-19$ & 375 & 50 & 133.3 & 325 & 86.7 & 30 & 8.0 & 345 & 92.0 & 39 & 10.4 & 336 & 89.6 & 73 & 19.5 & 302 & 80.5 & 64 & 17.1 & 311 & 82.9 \\
\hline $20-32$ & 165 & 27 & 16.4 & 138 & 83.6 & 16 & 9.7 & 149 & 90.3 & 18 & 10.9 & 147 & 89.1 & 54 & 32.7 & 111 & 67.3 & 41 & 24.9 & 124 & 75.1 \\
\hline Female & 372 & 50 & 13.4 & 322 & 86.6 & 32 & 8.6 & 340 & 91.4 & 36 & 9.7 & 336 & 90.3 & 57 & 15.3 & 315 & 84.7 & 44 & 11.8 & 328 & 88.2 \\
\hline Male & 168 & 27 & 16.1 & 141 & 83.9 & 14 & 8.3 & 154 & 91.7 & 21 & 12.5 & 147 & 87.5 & 70 & 41.7 & 98 & 58.3 & 61 & 36.3 & 107 & 63.7 \\
\hline
\end{tabular}

TABLE 4b: Student's attitudes related to condom use.

\begin{tabular}{|c|c|c|c|c|c|c|c|c|c|c|c|c|c|}
\hline \multirow[t]{3}{*}{ Variable } & \multirow[t]{3}{*}{ Total } & \multicolumn{4}{|c|}{$\begin{array}{l}\text { A woman loses a man's respect if } \\
\text { she asks him to use a condom }\end{array}$} & \multicolumn{4}{|c|}{$\begin{array}{l}\text { I use condoms only if my sexual } \\
\text { partner wants me to use it }\end{array}$} & \multicolumn{4}{|c|}{$\begin{array}{l}\text { Condoms should only be used if having sex with } \\
\text { a person who is not the main sexual partner }\end{array}$} \\
\hline & & \multicolumn{2}{|c|}{ Agree } & \multicolumn{2}{|c|}{ Disagree } & \multicolumn{2}{|c|}{ Agree } & \multicolumn{2}{|c|}{ Disagree } & \multicolumn{2}{|c|}{ Agree } & \multicolumn{2}{|c|}{ Disagree } \\
\hline & & $n$ & $\%$ & $n$ & $\%$ & $n$ & $\%$ & $n$ & $\%$ & $n$ & $\%$ & $n$ & $\%$ \\
\hline $15-19$ & 375 & 18 & 4.8 & 357 & 95.2 & 24 & 6.4 & 351 & 93.6 & 25 & 6.7 & 350 & 93.3 \\
\hline $20-32$ & 165 & 8 & 4.9 & 157 & 95.1 & 15 & 9.1 & 150 & 90.9 & 22 & 13.3 & 143 & 86.7 \\
\hline \multicolumn{14}{|l|}{ Sex } \\
\hline Male & 168 & 14 & 8.3 & 154 & 91.7 & 23 & 13.7 & 145 & 86.3 & 27 & 16.1 & 141 & 83.9 \\
\hline
\end{tabular}


disagreed with the statement that a woman loses a man's respect if she asks him to use a condom (96.8\% of female participants and $91.7 \%$ of male participants); that they only use condoms if their sexual partner wants to use them (95.7\% female participants and $86.3 \%$ of male participants); and that condoms should only be used if having sex with a person who is not the main sexual partner $(94.6 \%$ of female participants and $83.9 \%$ of male participants). About a third of the students and $41.7 \%$ of the male students said that condoms felt unnatural, and nearly a quarter of the students aged $20-32$ years and $36.3 \%$ of the male students said that condoms alter climax or orgasm.

Most participants had positive attitudes towards HIV-positive people, but 38 (7\%) participants were unwilling to be associated with or share living space with people living with HIV. Based on the relative importance index score, the most important attitudes towards people living with HIV, ranked in order of relative importance, were: (1) About $83.4 \%$ of students indicated that even if a family member had HIV, their relationship with them would remain good; (2) $20 \%$ of students said that sharing a house with HIV-positive people would be very difficult for them; and (3) $7.6 \%$ of students felt that people who get infected with HIV are promiscuous. Forty-one (7.6\%) students also said they do not want to be associated with HIV-positive people, and $6.4 \%$ of students felt that HIV-negative people should not be allowed to socialise with HIV-positive people. Students had positive attitudes towards treatment for HIV and AIDS. Around two-thirds (63.1\%) of the students agreed that HIV treatment would keep an HIV-positive person alive (ranked the most important attitude). Two hundred and seventy-four (50.8\%) students agreed that HIV medication really works (with a relative importance score of 2). Most of the respondents (69\% students) rejected the notion that antiretroviral (ARV) medication is poisonous (Table 5).

Condom use at last sex was higher when with a regular partner: female students $(n=147)$ and male students $(n=93)$. The difference is statistically significant $(p<0.001)$. Fewer female students $(n=53)$ and male students $(n=57)$ reported using condoms consistently with a non-regular partner $(p=0.049)$. More female students $(n=83)$ reported consistent condom usage (every time) with regular sex partners than male students $(n=54)$; however, the difference was not significant $(p=0.240)$ (Table 6).

\section{Discussion}

South Africa is battling an HIV and AIDS pandemic, which remains one of the primary social and health concerns in the country. Notwithstanding the outstanding effort by the Department of Health in implementing HIV and AIDS prevention strategies, South Africa is still the country worst

TABLE 6: Condom use among students.

\begin{tabular}{|c|c|c|c|c|c|}
\hline \multirow[t]{2}{*}{ Variable } & \multicolumn{2}{|c|}{ Female } & \multicolumn{2}{|c|}{ Male } & \multirow[t]{2}{*}{$p$} \\
\hline & $n$ & $\%$ & $n$ & $\%$ & \\
\hline \multicolumn{5}{|c|}{ Condom use at last sex with a partner } & $0.001 * * *$ \\
\hline Yes & 147 & 39.3 & 93 & 55.4 & \\
\hline No & 227 & 60.7 & 75 & 44.6 & \\
\hline \multicolumn{5}{|c|}{ Consistent condom use with partners } & 0.240 \\
\hline Every time & 83 & 38.8 & 54 & 42.5 & \\
\hline Almost every time & 36 & 16.8 & 30 & 23.6 & \\
\hline Sometimes & 31 & 14.5 & 18 & 14.2 & \\
\hline Never & 31 & 14.5 & 11 & 8.7 & \\
\hline Do not know & 33 & 15.4 & 14 & 11.0 & \\
\hline \multicolumn{5}{|c|}{ Condom use at last sex with a non-regular partner } & $0.002 * * *$ \\
\hline Yes & 59 & 42.7 & 71 & 62.8 & \\
\hline No & 79 & 57.3 & 42 & 37.2 & \\
\hline \multicolumn{5}{|c|}{ Consistent condom use with a non-regular partner } & $0.049 * * *$ \\
\hline Every time & 53 & 40.2 & 57 & 53.3 & \\
\hline Almost every time & 11 & 8.3 & 13 & 12.2 & \\
\hline Sometimes & 10 & 7.6 & 5 & 4.7 & \\
\hline Never & 17 & 12.9 & 15 & 14.0 & \\
\hline Do not know & 41 & 31.1 & 17 & 15.9 & \\
\hline \multicolumn{5}{|c|}{ Condom use at last sex with a commercial sex worker } & $0.001 * * *$ \\
\hline Yes & 57 & 30.7 & 55 & 49.6 & \\
\hline No & 129 & 69.3 & 56 & 50.4 & \\
\hline \multicolumn{5}{|c|}{ Consistent condom use with a commercial sex worker } & 0.138 \\
\hline Every time & 49 & 27.8 & 41 & 38.0 & \\
\hline Almost every time & 11 & 6.3 & 11 & 10.2 & \\
\hline Sometimes & 9 & 5.1 & 7 & 6.5 & \\
\hline Never & 38 & 21.6 & 15 & 13.9 & \\
\hline Do not know & 69 & 39.2 & 34 & 31.5 & \\
\hline
\end{tabular}

***, significant at $p<0.05$

TABLE 5: Attitudes of students towards people who are HIV-positive or have AIDS and HIV and/or AIDS treatment.

\begin{tabular}{|c|c|c|c|c|c|c|c|c|c|c|c|c|}
\hline \multirow[t]{2}{*}{ Statements } & \multicolumn{2}{|c|}{$\begin{array}{l}\text { Strongly } \\
\text { agree }\end{array}$} & \multicolumn{2}{|c|}{ Agree } & \multicolumn{2}{|c|}{$\begin{array}{l}\text { Neither agree } \\
\text { or disagree }\end{array}$} & \multicolumn{2}{|c|}{ Disagree } & \multicolumn{2}{|c|}{$\begin{array}{l}\text { Strongly } \\
\text { disagree }\end{array}$} & \multirow{2}{*}{$\begin{array}{c}\text { Relative } \\
\text { importance } \\
\text { index }\end{array}$} & \multirow[t]{2}{*}{ Rank } \\
\hline & $n$ & $\%$ & $n$ & $\%$ & $n$ & $\%$ & $n$ & $\%$ & $n$ & $\%$ & & \\
\hline \multicolumn{13}{|c|}{ Attitudes of students towards people who are HIV-positive or have AIDS } \\
\hline I do not want to be associated with HIV-positive people & 23 & 4.3 & 18 & 3.3 & 85 & 15.7 & 164 & 30.4 & 250 & 46.3 & 0.38 & 4 \\
\hline $\begin{array}{l}\text { Even if a family member had HIV, my relationship with them } \\
\text { would remain good }\end{array}$ & 298 & 55.2 & 152 & 28.2 & 48 & 8.9 & 15 & 2.8 & 27 & 5.0 & 0.85 & 1 \\
\hline $\begin{array}{l}\text { Staying in the same house or hostel with HIV-positive people } \\
\text { would be extremely difficult for me }\end{array}$ & 38 & 7.0 & 70 & 13.0 & 140 & 25.6 & 117 & 21.7 & 175 & 32.4 & 0.48 & 2 \\
\hline People who get infected with HIV are promiscuous & 16 & 3.0 & 25 & 4.6 & 210 & 38.9 & 115 & 21.3 & 174 & 32.2 & 0.45 & 3 \\
\hline $\begin{array}{l}\text { HIV-negative people should not be allowed to socialise with } \\
\text { HIV-positive people }\end{array}$ & 22 & 4.1 & 13 & 2.4 & 52 & 9.6 & 67 & 12.4 & 386 & 71.5 & 0.27 & 5 \\
\hline \multicolumn{13}{|l|}{ Attitudes of students towards HIV treatment } \\
\hline I do not trust that HIV treatment works & 23 & 4.3 & 26 & 4.8 & 165 & 30.6 & 173 & 32.0 & 153 & 28.3 & 0.45 & 3 \\
\hline HIV treatment will keep an HIV-positive person alive & 119 & 22.0 & 222 & 41.1 & 137 & 25.4 & 39 & 7.2 & 23 & 4.3 & 0.74 & 1 \\
\hline You can share HIV treatment with your partner & 14 & 2.6 & 27 & 5.0 & 144 & 26.7 & 105 & 19.4 & 250 & 46.3 & 0.40 & 4 \\
\hline HIV medicine really works & 95 & 17.6 & 179 & 33.2 & 227 & 42.0 & 16 & 3.0 & 23 & 4.3 & 0.71 & 2 \\
\hline
\end{tabular}

HIV and AIDS, human immunodeficiency virus and acquired immunodeficiency syndrome; ARV, antiretroviral. 
affected by the HIV and AIDS pandemic, with the youth between the ages of 15 and 24 years being the hardest hit. ${ }^{5}$ Young female students are reported to have higher infection rates owing to a lack of knowledge and poor attitudes towards condom use and risky sexual behaviours, ${ }^{6}$ making them twice as likely as male students to be infected with HIV. ${ }^{3,6,8}$ This study was aimed at determining gender differences in knowledge, attitudes and behaviour in relation to HIV and AIDS among students at a private higher education institution in Johannesburg, South Africa.

Findings in this study indicate that there is no significant difference between male and female students in terms of their general knowledge of HIV and AIDS. However, it is noteworthy that female students had significantly less knowledge of unprotected anal sex as a risk factor for HIV and AIDS. In addition, a smaller proportion of female students reported condom use at last sex, compared to their male counterparts. This could be attributed to the female population having limited control over male condom usage..$^{19}$ The complex power imbalance in this scenario, with most females not having the power to negotiate condom use with their partners, is the likely underlying cause. ${ }^{20,21}$

Moreover, $8.3 \%$ of male students and $3.8 \%$ of female students believed that AIDS can be cured. Although these percentages are comparatively low, they are equally as disconcerting as the results in Haroun et al., ${ }^{22}$ who found that just over $20 \%$ of a sample of university students in the United Arab Emirates did not know whether HIV and AIDS could be cured or not. This poor knowledge of basic messages relating to HIV and AIDS is a likely reason as to why the youth engage in risky sexual behaviour and why the prevalence of HIV infection among them is high. ${ }^{23}$

Regarding risky sexual behaviour, this study revealed notable differences between male and female students, with the latter $(57.3 \%)$ and the former (37.2\%) reporting not having used a condom at last sex with a non-regular partner. As the chisquare test revealed no significant variation in attitudes between male and female students, we opted to investigate the entire sample's attitudes rather than to compare male and female students. Results revealed that the majority of participants $(83.4 \%)$ had a positive attitude towards people living with HIV and AIDS. This differs from previous findings where the majority indicated negative attitudes towards people living with HIV and AIDS. ${ }^{22}$ Positive attitudes such as these have been attributed to parental and social communication aimed at promoting HIV and AIDS awareness among the youth. ${ }^{24}$

\section{Limitations}

There were a disproportionate number of female students, compared to male students in this study. It is possible that this might have affected the robustness of the chi-square test and therefore skewed the findings. In addition, the sample came from one private higher education institution in Johannesburg, South Africa. It would have been ideal for more institutions to be included in the study to get a better picture of the knowledge levels, attitudes and behaviours towards HIV and AIDS at private higher education institutions in the Johannesburg metropolitan area. Notwithstanding these limitations, these findings could serve as a springboard for national research that would be more representative of the wider student population in both private and public higher education institutions.

\section{Recommendations}

It is recommended that future research should sample students from several private and public higher education institutions with a representative number of both male and female students. This could then inform interventions that reduce HIV infection among the youth in South Africa through improved attitudes facilitated by communication at both social and parental levels. ${ }^{24}$ It is further recommended that sex education in secondary schools should be introduced to close the gender gap in knowledge and prevent risky sexual behaviours.

\section{Conclusion}

This study found that the level of HIV and AIDS knowledge in female students was not significantly different than in male students although risky sexual behaviour in female students was more frequent. In addition to the existing interventions aimed at reducing the prevalence of HIV and AIDS among the youth in South Africa, efforts towards implementing interventions at educational as well as social and family-based levels are imperative.

\section{Acknowledgements}

We would like to acknowledge the participants for their participation in this study.

\section{Competing interests}

The authors declare that they have no financial or personal relationships that may have inappropriately influenced them in writing this article.

\section{Authors' contributions}

N.K. and M.M. conceptualised the study, collected data and did the write-up of the introduction, method and discussion sections. T.B. did data analysis and the write-up of the results section.

\section{Funding Information}

This study was funded by Monash South Africa research office.

\section{Data availability statement}

Data sharing is not applicable to this article as no new data were created or analysed in this study. 


\section{Disclaimer}

The views expressed in this article are the authors' own and not an official position of the institution or the funder.

\section{References}

1. WHO. HIV and AIDS. WHO [homepage on the Internet]. 2018 [cited 2019 May 17] Available from: https://www.who.int/gho/hiv/en/

2. Miller CL, Nkala B, Closson K, et al. The Botsha Bophelo Adolescent Health Study: A profile of adolescents in Soweto, South Africa. South Afr J HIV Med. 2017;18(1):1-10. https://doi.org/10.4102/sajhivmed.v18i1.731

3. Dwyer-Lindgren L, Cork MA, Sligar A, et al. Mapping HIV prevalence in subSaharan Africa between 2000 and 2017. Nature [serial online]. [cited 2019 May 17]. Available from: http://www.nature.com/articles/s41586-019-1200-9

4. UNAIDS. Global HIV \& AIDS statistics - 2018 fact sheet [homepage on the Internet]. UNAIDS; 2019 [cited 2019 May 18]. Available from: https://www. unaids.org/en/resources/fact-sheet

5. Stats SA. Mid-year population estimates 2019 [homepage on the Internet]. [cited 2019 Nov 2]. Available from: http://www.statssa.gov.za

6. Hogg R, Nkala B, Dietrich J, et al. Conspiracy beliefs and knowledge about HIV origins among adolescents in Soweto, South Africa. PLoS One. 2017;12(2):1-9. https://doi.org/10.1371/journal.pone.0165087

7. Yaya S, Ghose B, Udenigwe $O$, Shah V, Hudani A, Ekholuenetale M. Knowledge and attitude of HIV and AIDS among women in Nigeria: A cross-sectional study. Eur Public Health. 2019;29(1):111-117. https://doi.org/10.1093/eurpub/cky131

8. Kharsany ABM, Karim QA. HIV infection and AIDS in sub-Saharan Africa: Current status, challenges and opportunities. Open AIDS J. 2016;10(1):34-48. https://doi. org/10.2174/1874613601610010034

9. Nubed CK, Akoachere J-FTK. Knowledge, attitudes and practices regarding HIV and AIDS among senior secondary school students in Fako Division, South West Region, Cameroon. BMC Public Health [serial online]. 2016;16(1):847. West Region, Cameroon. BMC Public Health
https://doi.org/10.1186/s12889-016-3516-9

10. Wang SC, Lui JHL, Vega G, Waldrop M, Garris J. The moderating effect of alcohol use on protective and risky sex behaviors among college students in the Southeast United States. J Am Coll Heal. 2018;66(7):546-552. https://doi.org/10.1080/0744 8481.2018.1431916

11. Younge SN, Wade BH, Geter A, Holliday RC, Trawick C. Condom attitudes and condom use among first year college men attending a historically black institution. Am J Health Stud [serial online]. 2018;33(2):80-88.

12. Vijay C, Johnson A, Rajitha K, Archana M, Rakesh J. Knowledge and beliefs regarding contraception, HIV and AIDS and sexually transmitted infections among young adults. Int J Recent Sci Res. 9(4):26211-26216. https://doi.org/10.24327/ ijrsr.2018.0904.2014
13. Egenti BN, Odiba EP, Dangana A, Yalma RM, Nasir IA. Knowledge, attitude and factors affecting voluntary HIV counseling and testing services among women in an Abuja suburb community. Heal Sci Res. 2018;5(2):50-58.

14. Dove M, Silver E, Swenson R. Beliefs associated with attitudes about HIV testing among adolescents at risk. J Adolesc Heal [serial online]. 2018 [cited 2019 May 17];62(2):S116. Available from: https://linkinghub.elsevier.com/retrieve/pii/ S1054139X17307656

15. Protogerou C, Johnson B, Psychology $\mathrm{MH}-\mathrm{H}$. An integrated model of condom use in Sub-Saharan African youth: A meta-analysis. psycnet.apa.org [homepage on the Internet]. 2018 [cited 2019 May 17]. Available from: https://psycnet.apa.org/ record/2018-19113-001

16. Charles S, Drobatz L, Dorey R. Knowledge, attitudes, and beliefs about sexual health and behavior in Huye, Rwanda. 2018 [cited 2019 May 17]. Available from: https://jdc.jefferson.edu/cgi/viewcontent.cgi?filename $=0$ \&article $=1027 \&$ conte $\mathrm{xt}=$ si_phr_2021_phase1\&type=additional

17. Sun CJ, Seloilwe ES, Magowe M, Dithole KS, Miller KS, St. Lawrence JS. Gender differences in sexual and reproductive health protective and risk factors of Batswana adolescents: Implications for parent and adolescent interventions. AIDS Educ Prev. 2018;30(1):35-46. https://doi.org/10.1521/ aeap.2018.30.1.35

18. World Population Review. Johannesburg population 2019 (demographics, maps, graphs) [homepage on the Internet]. 2019 [cited 2019 May 17]. Available from: http://worldpopulationreview.com/world-cities/johannesburg-population/

19. Zuma K, Shisana O, Rehle TM, et al. New insights into HIV epidemic in South Africa: Key findings from the National HIV prevalence, incidence and behaviour survey, 2012. Afr J AIDS Res. 2016;15(1):67-75. https://doi.org/10.2989/1608590 6.2016 .1153491

20. Khuzwayo N, Taylor M. Exploring the socio-ecological levels for prevention of sexual risk behaviours of the youth in uMgungundlovu District Municipality, KwaZulu-Natal. Afr J Prim Health Care Fam Med. 2018;10(1):1-8. https://doi. org/10.4102/phcfm.v10i1.1590

21. Mabaso M, Sokhela Z, Mohlabane N, Chibi B, Zuma K, Simbayi L. Determinants of HIV infection among adolescent girls and young women aged 15-24 years in South Africa: A 2012 population-based national household survey. BMC Public Health. 2018;18(1):183. https://doi.org/10.1186/s12889-018-5051-3

22. Haroun D, El Saleh O, Wood L, Mechli R, Al Marzouqi N, Anouti S. Assessing knowledge of, and attitudes to, HIV and AIDS among university students in the United Arab Emirates. PLoS One. 2016;11(2):1-11. https://doi.org/10.1371/ journal.pone.0149920

23. Talwar P, Rahman MFBA. Assessment of HIV knowledge among university students using the HIV-KQ-18 scale: A cross-sectional study. South East Asia J Public Heal. 2015;5(1):33-38. https://doi.org/10.3329/seajph.v5i1.24849

24. Adeleke IT, Azeez BA, Aliyu D, Ogundiran LM, Salami A, Adeoye WA. HIV and AIDS awareness among secondary schools' adolescents in south-western Nigeria: A correlate to strengthen advocacy and strategic sexuality education programs. Am J Health Res. 2015;3(1-1):61-67. https://doi.org/10.11648/j.ajhr. s.2015030101.19 